\title{
Intradural disc herniation: A case report and literature review
}

\section{Intradural disk hernisi: Olgu sunumu ve literatür taraması}

\author{
Murat Kiraz ${ }^{1 \odot}$ \\ ${ }^{1}$ Hitit Üniversitesi Erol Olçok Eğitim ve Araştırma Hastanesi, Beyin ve Sinir Cerrahisi Kliniği, Çorum.
}

Atıf/Cite as: Kiraz M. Intradural disc herniation: A case report and literature review. J Nervous Sys Surgery 2021;7(3):112-115.

Geliş tarihi/Received: 25.11.2021 Kabul tarihi/Accepted: 27.12.2021 Yayın tarihi/Publication date: 16.01.2022

\begin{abstract}
Background: Intradural disc herniation (IDH) is rare and is thought to be caused by posterior longitudinal ligament and posterior adhesions. MRI findings are inadequate for definitive diagnosis. We reported a patient with an L4-5 IDH and reviewed the literature.

Case Description: A 71-year-old male patient presented with acute exacerbation of right lower extremity radiculopathy. MRI with/without contrast suggested IDH and spinal cord compression at the L4-5 spine level. While elective surgery was planned for the patient who did not have motor deficits at the time of admission, he underwent emergency surgery due to sudden urinary incontinence. At surgery, the disc herniation was appropriately resected, the dura was closed.

Conclusion: Although MRI is helpful in the diagnosis of IDH, the definitive diagnosis is made intraoperatively. In surgery, both the extradural and intradural disc components should be removed and as small laminectomy and dura incision as possible.
\end{abstract}

Keywords: Intervertebral disc herniation, intraoperative diagnosis, emergency surgery

ÖZ

Amaç: İntradural disk herniasyonu (IDH) nadirdir ve posterior longitudinal ligament ve posterior adezyonlardan kaynaklandığı düşünülmektedir. MRG bulguları kesin tanı için yetersizdir. L4-5 İDH'li bir hastayı bildirdik ve literatürü gözden geçirmeyi amaçladık.

Olgu Sunumu: 71 yaşında erkek hasta sağ alt ekstremite radikülopatisinin akut alevlenmesi ile başvurdu. Kontrastl1/kontrastsız MRG, L4-5 omurga seviyesinde İDH ve omurilik kompresyonu gösterdi. Başvuru anında motor defisiti olmayan hastaya elektif cerrahi planlanırken ani idrar kaçırma nedeniyle acil ameliyata alındı. Ameliyatta disk hernisi uygun şekilde rezeke edildi, dura kapatıldı.

Sonuç: MRG, IDH tanısında yardımcı olmakla birlikte kesin tanı intraoperatif olarak konur. Ameliyatta hem ekstradural hem de intradural disk bileşenleri çıkarılmalı ve mümkün olduğunca küçük laminektomi ve dura insizyonu yapılmalıdır.

Anahtar Kelimeler: İntradural disk herniasyonu, manyetik rezonans görüntüleme, intraoperatif

Sorumlu yazar/Corresponding author: Murat Kiraz, Hitit Üniversitesi Erol Olçok Eğitim ve Araştırma Hastanesi, Beyin ve Sinir Cerrahisi Kliniği, Çorum. kirazmurat@gmail.com / 0000-0001-6692-444X

(C) Telif hakkı Sinir Sistemi Cerrahisi Dergisi

Bu dergide yayınlanan bütün makaleler Creative Commons 4.0 Uluslararası Lisansı (CC-BY) ile lisanslanmıştır.

CC Copyright Journal of Nervous System Surgery.

Licenced by Creative Commons Attribution 4.0 International (CC BY). 


\section{INTRODUCTION}

Intradural disc herniation (IDH) represents between $0.26 \%$ and $0.30 \%$ of all discs, and $92 \%$ occur in the lower lumbar spine, mostly at the L4-L5 level ${ }^{(1,2)}$. First described Dandy in 1942 (3). Typically, patients are in the 6th decade of acute low back pain accompanied by the rapid onset of paresis ${ }^{(4)}$. In some cases, it can mimic spinal tumors ${ }^{(5)}$. Magnetic resonance imaging (MRI) is the most common diagnostic tool for lumbar disc herniation. Various MRI findings such as intradural disc-like "hawk-bill" and "Y" sign have been described in the literature with disc herniation ${ }^{(6-9)}$. Many of these findings may not be seen in every case, and surgery is the gold standard for diagnosis of intradural disc herniation suspected on MRI. In this article, we will present a patient who was operated with the diagnosis of intradural disc herniation.

\section{CASE DESCRIPTION}

71 years male presented with right side lower limb radiculopathy for one month. Radiculopathy became very severe the night before, he applied to the outpatient clinic. Clinical examination revealed an only sensory deficit in right side L4 and L5 dermatomes with no associated motor deficit. A prior conventional lumbar MRI described a large L4-5 superior and inferior migration, huge right paramedian disc herniation. IDH was suspected on MRI (Figure 1). Contrast lumbar MRI for spinal tumor exclusion revealed no contrast pathology. Urinary incontinence started 6 hours after hospitalization. The patient underwent emergency surgery. During the operation, no hernia was found in the epidural space despite. The dura was opened in a 1,5 $\mathrm{cm}$ small midline incision under an operating microscope, showing placed under spinal nerve roots. Disc material which has not adhered to any tissue was easily removed, and after disc resection, the dura was sutured closed (Figure 2).

\section{DISCUSSION}

When the preoperative MRIs of our patient are examined, it is seen that there is an intradural disc herniation at the L4-L5 level. As in our case, it has been reported that most of the intradural discs are at the L4-L5 level ${ }^{(10)}$. A patient diagnosed with IDH should have a good anamnesis and a history of spinal trauma or surgery ${ }^{(11)}$. Our case had no history of previous trauma or spinal surgery. IDH often has symptoms of paresis, low back pain, or cauda equina syndromes. Other case reports also confirmed that cauda equina syndrome often accompanies it ${ }^{(12)}$. In our case, urinary incontinence started after a while.

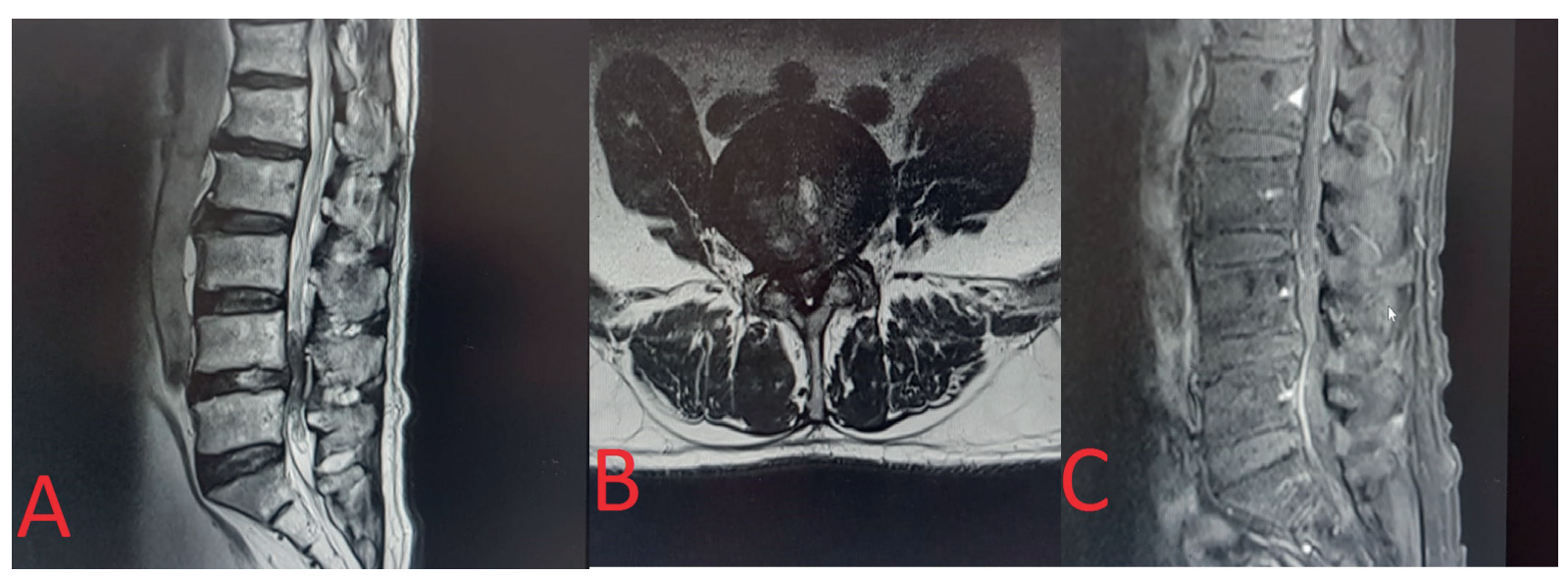

Figure 1. A- sagittal T2-weighted MRI, B- axial T2-weighted MRI, C- sagittal post contrast T1-weighted MRI 


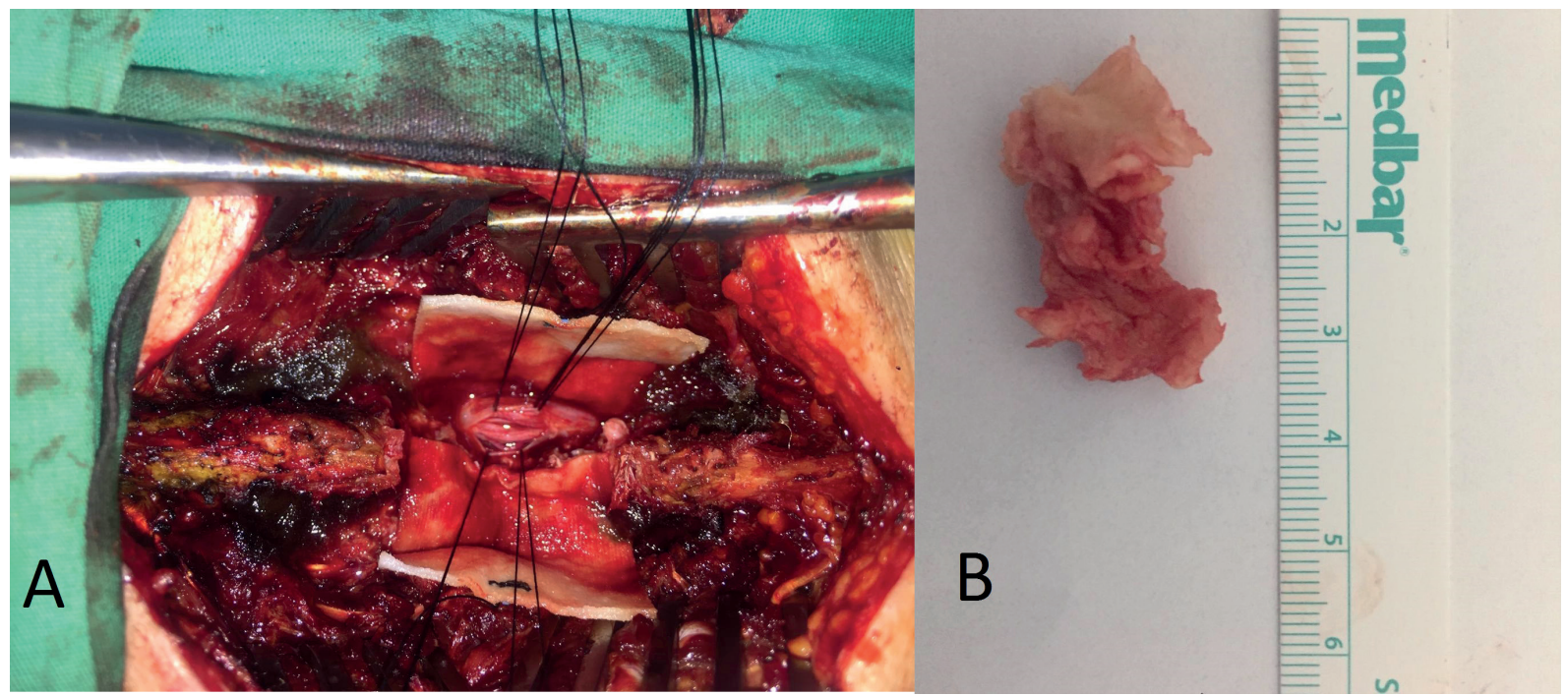

Figure 2. A- intraoperative images B- removed intradural disc material

Numerous signs, which should alert the surgeon, may be present in MRI: 'hawk-beak sign' or 'Y sign'. However, most of those signs are not specific and can not be observed in the majority of cases (8). IDH should be differentiated from other pathological tissues which may be found inside the spinal canal, micro-metastasis, neuroma, meningioma or cyst. The final diagnosis is possible to thank contrast-enhanced MRI ${ }^{(13)}$.

Adhesions can be seen between the anterior surface of the dura and the posterior longitudinal ligament ${ }^{(14,15)}$. Adhesions are mostly observed in the L4-5 disc distance ${ }^{(14,15)}$. For all that, without trauma and spinal surgery, IDH may have a congenital cause, such adhesions have also been seen in stillbirth autopsies ${ }^{(16)}$.

The surgical technique is primarily performed by microscopic discectomy and resection of the disc material at the extradural distance if any. Extradural disc material may not be present as in our case. The laminectomy is followed by a midline dural incision and resection of the disc material in the intradural space. The surgical procedure is relatively difficult and can result in failed back surgery syndrome ${ }^{(17)}$. If failed back surgery syndrome develops, different new techniques can be used for pain and other complications ${ }^{(18,19)}$. In our case, we performed a laminectomy and a $1.5 \mathrm{~cm}$ dura incision as small as possible. Thus, there was no need for stabilization/fusion surgery. Besides, we reduced the likelihood of CSF fistula due to the small incision of the dura. Thus, the duration of hospitalization is reduced.

\section{CONCLUSION}

Intradural disc herniation is characterized by uncommon and sudden onset low back pain and paresis. Contrast/non-contrast MRI should be performed in cases where intradural disc herniation is suspected. Although MRI findings indicate intradural disc herniation, the definitive diagnosis is intraoperative. Small laminectomy and dura incision shorten the length of hospital stay.

Conflict of interest: There is no conflict of interest in our study.

Funding: No financial support was received in our study. 
Çıkar çatışması: Çalışmamızda herhangi bir çıkar çatışması bulunmamaktadır.

Finansal destek: Çalışmamızda finansal destek alınmamıştır.

\section{REFERENCES}

1. Oztürk A, Avci E, Yazgan P, Torun F, Yücetaş S, Karabağ H, et al. Intradural herniation of intervertebral disc at the level of lumbar 1-lumbar 2. Turk Neurosurg 2007; $17: 134-7$.

2. Arigio RM. Et al. Intradural disc herniation at the L1L2 level: A case report and literature review. Surgical Neurology International - 2019 - 10(196). https://doi. org/10.25259/SNI 452 2019

3. Dandy WE: Serious complications of ruptured intervertebral dics. JAMA 11:474-475, 1942. https://doi. org/10.1001/jama.1942.02830230008002

4. Koc RK, Akdemir H, Oktem IS, Menku A: Intradural lumbar disc herniation: report of two cases. Neurosurg Rev 24:44-47,2001.https://doi.org/10.1007/PL00011967

5. Özdemir Ö, and Solmaz İ, 2019. Spinal Gliomlar. Türk Nöroşirürji Dergsi, 29(3), pp.357-360.

6. Liu CC, Huang CT, Lin CM, Liu KN. Intradural disc herniation at L5 level mimicking an intradural spinal tumor. Eur Spine J. 2011;20(Suppl 2):S326-9. https://doi. org/10.1007/s00586-011-1772-z

7. Arrigo RT, Kalanithi P, Boakye M. Is cauda equina syndrome being treated within the recommended time frame? Neurosurgery. 2011;68:1520-6. https://doi. org/10.1227/NEU.0b013e31820cd426

8. Sasaji T, Horaguchi K, Yamada N, Iwai K. The specific sagittal magnetic resonance imaging of intradural extraarachnoid lumbar disc herniation. Case Rep Med 2012. 2012 383451. https://doi.org/10.1155/2012/383451

9. Sharma A, Singh V, Sangondimath G, Kamble P. Intradural disc a diagnostic dilemma: Case series and review of literature. Asian J Neurosurg 2018;13:1033-6. https://doi.org/10.4103/ajns.AJNS_55_17
10.D'Andrea G, Trillò G, Roperto R, Celli P, Orlando ER, Ferrante L. Intradural lumbar disc herniations: The role of MRI in preoperative diagnosis and review of the literature. Neurosurg Rev. 2004;27:75-80. https://doi. org/10.1007/s10143-003-0296-3

11. Orakcioglu B, Dao Trong HP, Jungk C, Unterberg A. Against the odds: Massive lumbar intradural disk herniation in the elderly. Global Spine J. 2015;5:e84-7. https://doi.org/10.1055/s-0035-1546952

12.Ducati LG, Silva MV, Brandão MM, Romero FR, Zanini MA. Intradural lumbar disc herniation: Report of five cases with literature review. Eur Spine J. 2013;22:1436. https://doi.org/10.1007/s00586-012-2516-4

13.Baranowski P, Baranowska A, Baranowska J, Konieczny R. Intradural disc herniation - report of two cases Pol Med J, 2019; XLVII (277); 28-30.

14.Blikra G (1969) Intradural herniated lumbar disc. J Neurosurg 31:676-679. https://doi.org/10.3171/ jns.1969.31.6.0676

15.Yildizhan A, Pasaoglu A, Okten T, Ekinci N, Aycan K, Aral O (1991) Intradural disc herniations: pathogenesis, clinical picture, diagnosis and treatment. Acta Neurochir (Wien) 110(3-4): 160-165. https://doi.org/10.1007/ BF01400685

16.Aydin MV, Ozel S, Sem O, Erdogan B, Yildirim T (2004) Intradural disc mimicking: a spinal tumor lesion. Spinal Cord 42:52-54. https://doi.org/10.1038/sj.sc.3101476

17.Özdemir Ö, 2021 Failed Back Surgery Syndrome. Regional Pain Syndromes Of The Muscular Skeleton System 978-605-7146- pp.66-71

18.Kaya M.E, Özdemir Ö, Yılmaz A, 2019 Yaşlanan omurgada nöromodülasyon / spinal kord stimülasyonu uygulamaları. Türk Nöroşirürji Derneği Spinal ve Periferik Sinir Cerrahisi Öğretim ve Eğitim Grubu Yaşlanan Omurga, pp.599-603

19.Kiraz, M., Cevik, S., Demirel, A., Gergin, Y.E. and Ozdemir, O., 2018. Nanoteknoloji ve nanonöroşirürji. 